\title{
Phytochemical Screening and Antimicrobial Activity of Ethanolic Extract of Handal Fruit CitrullusColocynthisin North Kordofan
}

\author{
Inaam A. M. Salim ${ }^{1}$, Mohamed. H. Ibrahim ${ }^{2}$ \\ ${ }^{1,2}$ Department of Chemistry, Faculty of Science, University of Kordofan, El Obeid, Sudan
}

\begin{abstract}
HandalCitrullusColocynthis is a medicinal plant traditionally used in Sudan and many other African countries as an antiinflammatory, purgative, anti-rheumatic and anti-diabetic. This study was carried out in Elobied North Kordofan state, theaim of this study was to analyze the phytochemical constituents of HandalCitrullusColocynthis fruit, in order to determine its active ingredients, and test the antimicrobial activity of the crude ethanolic extract of the fruit against some bacteria and fungi. The results demonstrated the presence of alkaloids, flavonoids and terpenoids, tannins, Saponins and anthraquinones were not detected. Different concentrations of extract were examined against four typesof bacteria and Trichophton fungi,. The results showed higher concentrations are more active in bacteria and fungi with exception of Pseudomonas bacteria which showed opposite result. Hence,it can be used to cure diseases caused by these microorganisms.
\end{abstract}

Keywords: CitrullusColocynthis, Antimicrobial.

\section{Introduction}

The use of plants as source of remedies for the treatment of many diseases dated back to the prehistory and people of all continents have this old tradition. The search for agents to cure infectious diseases begins long before people were aware of the existence of microbes. These early attempts used natural substances, usually native plants or their extracts and many of these herbal remedies proved successfully. The effective substances of many plant species are isolated for direct use as drugs, lead compound or pharmacological agents.

Nowadays, medicinal plants receive attention to research centers because of their special importance in safety of communities. The curative properties of medicinal plants are mainly due to the presence of various complex chemical substance of different composition which occurs as secondary metabolites. They are grouped as alkaloids, glycosides, flavonoids, saponins, tannins, carbohydrates and essential oils. Plant based natural constituents can be derived from many part of the plant like bark, leaves, flowers, roots, fruits, seeds, etc. Many plants possess antimicrobial activities and are used for treatment of different diseases] 1[

Citrulluscolocynthis belongs to the family cucurbitaceae, members of this family are generally dioecious herbs which may be prostate or climbing by means of tendrils fruit is fleshy and many fruits are used as vegetable or as edible fruits. Citrulluscolocynthis is small scarbid perennial creeping herb which prostate or climbing stem, bearing smooth spherical fruits which are mottled green when young and somewhat yellow when ribe. Colocynthis was well known to Greeks and Romans, both Dioskuides and Pliny being familiar with it. The drug was equally known to the Arabian physicians and was produce in Cyprus and Spain during the ages. It is mentioned in Anglo-Saxon herbal of eleven century. It is native of warmer parts of Asia, Syria, Egypt and Martine region of the Mediterranean. It is cultivated to some extent in Spain, Sicily and Morocco for purpose of export]2[.Medicinal plants an important part of our natural wealth. They serve as important therapeutic as well valuable raw materials for manufacturing numerous traditional and modern medicines ]3[.Medicinal plants represent a rich source of antimicrobial agents, plant are used medicinally in different countries and are source of many potent and powerful drugs. The uses for therapy is an ancient practice though much work has been done on ethno medicinal plants and there is still need to seek plants with medicinal value to combat diseases, because synthetic drugs are not only expensive and inadequate for the treatment of diseases. Moreover, there are considerable economic benefits in the development of indigenous medicinal plants for the treatment of various diseases ]4[.Fruits seemed to be richer in active compounds than the leaves. Consequently, Petroleum ether extracts showed better mortality results than water and ethanol extracts, but all showed significant effects. The fruits were more potent than the leaves, and in most cases the activities increased in relation to concentration and exposure time]5.[

\section{Materials and Methods}

\subsection{Plant Source}

C.colocynthis fruits (fresh green) were collected (about $1 \mathrm{~kg}$ ) from Alhajalaien village -North Kordofan (western Sudan) in December 2012.C.colocynthis fruits were cut into slides and air dried in dark place at room temperature for 7 days and powdered mechanically. 


\section{International Journal of Science and Research (IJSR) \\ ISSN (Online): 2319-7064 \\ Index Copernicus Value (2013): 6.14 | Impact Factor (2014): 5.611}

\subsection{Methods}

\subsubsection{Preparation of extract}

The dried powdered fruit (100g) was extracted with absolute ethanol $98 \%$ by maceration in conical flasks for 24 hours at room temperature. The crude ethanol extract was filtered using filter paper. The organic solvent was removed by evaporation to dryness at room temperature.

\subsubsection{Phytochemical screening of the crude extract}

Preliminary phytochemical screening has been carried out in order to have an idea of the different classes of constituent in the plant. Necessary to correlate the nature of chemical constituents with the antimicrobial activity. The dried extracts were first reconstituted in the respective solvent (ethanol) used for their extraction (prepared extract), and then subjected to qualitative chemical screening for the identification of the various classes of phytoconstituents according to methods described by Harborne]6[. The screening covered mainly alkaloids, saponins, flavonoids, tannins, sterols and lor triterpenes, and anthraquinones.

\subsubsection{Alkaloids test:-}

$30 \mathrm{ml}$ aliquot of the prepared extract was evaporated to dryness in an evaporating dish on a water bath. $5 \mathrm{ml}$ of $2 \mathrm{~N} \mathrm{HCl}$ was added to the dried samples and stirred while heating on the water bath for 10 minutes, cooled, filtered and divided equally into three test tubes:-

- To the first portion few drops of Mayer reagent were added, white buff precipitate was taken as presumptive evidence for the alkaloids.

- To the second portion few drops of Dragendrrofs reagents were added, yellowish- orange precipitate was taken as an evidence for the presence of alkaloids. The third portion treated with few drops of Wagner reagent and turbidity or precipitate was considered as evidence for the presence of alkaloids.

\subsubsection{Saponins test}

About $1 \mathrm{~g}$ of the dried powdered plant material was extracted with boiling distilled water. After cooling, the extract was placed in a clean test tube. The tube was Stoppard and vigorously shaken for about 30 second, then allowed to stand for 15-20 min. Frothing indicated the presence of saponins as follows: no froth = negative; froth less $1 \mathrm{~cm}=$ weakly positive; froth $1 \mathrm{~cm}=$ medium; froth $1-2 \mathrm{~cm}$ high positive; and froth greater than $2 \mathrm{~cm}=$ strongly positive.

\subsubsection{Flavonoids test:-}

A portion of $40 \mathrm{ml}$ of prepared extract was evaporated to dryness on a water bath, cooled, and residue was defatted several times with petroleum ether. The defatted residue was dissolved in $15 \mathrm{ml}$ of $96 \%$ ethanol and filtered. The filtrate was used for the following tests:

1) To $3 \mathrm{ml}$ of the filtrate in a test tube, $1 \mathrm{ml}$ of $1 \%$ aluminum chloride solution in methanol was added. Formation of a yellow color indicated the presence of flavonoids.
2) To $3 \mathrm{ml}$ of the filtrate in a test tube, $1 \mathrm{ml}$ of potassium hydroxide solution was added .a dark yellow color indicated the presence of flavonoid compounds .

3) To $3 \mathrm{ml}$ of the filtrate, $0.5 \mathrm{ml}$ of concentrated $\mathrm{HCl}$ and a few magnesium turnings $(0.5 \mathrm{~g})$ were added. Production of a definite color change to pink or red was taken as presumptive evidence that flavonoids were present in the plant sample.

\subsubsection{Tannins Test}

$25 \mathrm{ml}$ of the prepared extract were evaporated to dryness on a water bath. The residue extracted several times with $10 \mathrm{ml}$ hexane and filtered. The insoluble residue was stirred with 10 $\mathrm{ml}$ of hot saline solution the mixture was cooled and filtered $.5 \mathrm{ml}$ of this solution was treated with few drops of the Gelatin- salt reagents. Formation of an immediate precipitate was taken as evidence for the presence of tannins. Positive tests were confirmed by the addition of drops of $1 \% \mathrm{FeCl}_{3}$ followed by formation of characteristic blue, blue- black or blue-green color and precipitation.

\subsubsection{Sterols and triterpenes tests}

$40 \mathrm{ml}$ of the prepared extract was evaporated to dryness on water bath and the cooled residue was stirred several times with petroleum ether to remove most of the coloring materials. The residue was dissolved in acetic anhydride $(0.5 \mathrm{ml})$ and chloroform $(0.5 \mathrm{ml})$. The solution was transferred into a dry test tube and few drops of concentrated sulphuric acid were poured carefully down the walls of the test tube so as to form a lower layer. Brownish -red or violet ring at the zone of contact with supernatant and green or violet coloration denoted the presence of sterols and lor triterpenes.

\subsubsection{Anthraquinones test:-}

$1 \mathrm{~g}$ of powdered plants sample was boiled with $10 \mathrm{ml}$ of $0.5 \mathrm{~N}$ $\mathrm{KOH}$ containing $1 \mathrm{ml}$ of $3 \% \mathrm{H}_{2} \mathrm{O}_{2}$ solution. The mixture was boiled, cooled, filtered and $5 \mathrm{ml}$ filtrate was acidified with 10 drops of glacial acetic acid. This acidified mixture was shaken with $10 \mathrm{ml}$ of benzene and allowed to separate. $5 \mathrm{ml}$ aliquot of the benzene solution was shaken with $3 \mathrm{ml}$ of $10 \%$ ammonium hydroxide solution and the two layers allowed separating. The presence of anthraquinoes was indicated by pink or red coloration of the lower alkaline.

\subsubsection{Screening of the crude extracts for Antimicrobial Activities.}

$1 \mathrm{~g}$ of the crude ethanol extract was suspended in $10 \mathrm{ml}$ ethanol to give $100 \mathrm{mg} / \mathrm{ml}$ concentration. The suspension obtained was employed for antimicrobial assay.

\subsubsection{Organisms test}

Most bacteria can be divided into two groups based on a stain developed by the Danish physician Hans Christian Gram in 1889. This procedure was based on the fact that Gram positive bacteria retain a crystal violet iodine complex through decolourization with alcohol or acetone and Gram negative bacteria do not. Gram positive bacteria possess a thick peptidoglycan layer in their cell wall whereas Gram negative bacteria possess a thin peptidoglycan layer plus a

\section{Volume 4 Issue 11, November 2015}




\section{International Journal of Science and Research (IJSR) \\ ISSN (Online): 2319-7064 \\ Index Copernicus Value (2013): 6.14 | Impact Factor (2014): 5.611}

lipopolysaccharide outer membrane. The Gram stain is important because Gram positive and Gram negative bacteria have differing susceptibilities to a variety of antibiotics.

\subsubsection{Bioassays}

In recent years, established antimicrobial drugs have become less effective against many infectious agents. A 1994 report from the centers for disease control point out the concern not only about the possibility of a post antibiotic era, but also, our lenuous ability to detect, contain, and prevent emerging diseases. In vitro antimicrobial screening via the agar diffusion technique will provide the required preliminary observation to select among the crude plant extracts those with potentially useful properties for further chemical and biological investigation. The plate whole diffusion assay with modifications was adopted to assess the antibacterial and antifungal activities of the crude extract suspension. In this assay, inhibition of microbial growth caused by extracts could be detected as formation of a clear zone around holes filled with the extracts.

\subsubsection{Antibacterial Activity}

The cup-plate agar diffusion methods ]7[ was adopted with some minor modification to assess the antibacterial activity of the prepared extracts.

$1 \mathrm{ml}$ of the standardized bacterial stock suspension $10^{8}-10^{10}$ C.F.U/ml(contain formation unit was thoroughly mixed with $100 \mathrm{ml}$ of molten sterile nutrient agar which was maintained at $45^{\circ} \mathrm{C} .20 \mathrm{ml}$ aliquots of the inoculated nutrient agar were distributed into sterile Petri-dishes. The agar was left to incubated and each of these plates $(10 \mathrm{~mm}$ in diameter) were cut using sterile cork borer (No.4) and agar discs were removed. Alternate cups were filled with $0.1 \mathrm{ml}$ sample of each extracts using automatic micro liter pipette, and allowed to diffuse at room temperature for two hours. The plates were then incubated in the upright position at $37^{\circ} \mathrm{C}$ for 18 hours. Two replicates were carried out for each extracts against each of the test organisms. After incubation the diameters of the resultant growth inhibition zones were measured, averaged and the mean values were tabulated. ]8[

\subsubsection{Antifungal Activity}

The same method as for bacteria was adopted for antifungal activity. Instead of nutrient agar, sabouraud dextrose ager was used. The inoculated medium was incubated at $25^{\circ} \mathrm{C}$ for two days.

\section{Results and Discussion}

\subsection{Phytochemical screening of crude extract}

The results obtained from the fruit of CitrullusColocynthis extract are shown in the table
Table 3.1: Photochemical constituentsoC.colocynthis fruit

\begin{tabular}{|c|c|c|c|}
\hline No & Test & Reagents & Result \\
\hline 1 & Alkaloids & $\begin{array}{c}\text { Mayer's } \\
\text { Wagner's } \\
\text { Drangnendorff's }\end{array}$ & $\begin{array}{l}+\mathrm{ve} \\
+\mathrm{ve} \\
+\mathrm{ve} \\
\end{array}$ \\
\hline 2 & Flavonoids & $\begin{array}{c}\mathrm{HCL}+\mathrm{Mg} \text { turnings } \\
\mathrm{ALCl}_{3} \\
\mathrm{KOH} \\
\end{array}$ & $\begin{array}{l}+\mathrm{ve} \\
+\mathrm{ve} \\
+\mathrm{ve}\end{array}$ \\
\hline 3 & $\begin{array}{l}\text { Sterols and } \\
\text { Terpens }\end{array}$ & $\begin{array}{c}\text { Acetic anhydride }+ \text { Chloroform }+ \\
\text { Sulfuric acid }\end{array}$ & $+\mathrm{ve}$ \\
\hline 4 & Tannins & Saline solution+Gelatin-salt+FeCl ${ }_{3}$ & -ve \\
\hline 5 & Saponins & Boiling distilled water & -ve \\
\hline 6 & Anthraquinones & $\begin{array}{c}\mathrm{H}_{2} \mathrm{O}_{2}+\mathrm{KOH}+\text { glacial acetic } \\
\text { acid+benzene }+\mathrm{NH}_{4} \mathrm{OH} \\
\end{array}$ & -ve \\
\hline
\end{tabular}

+ve: Present, -ve: Not detected

\subsection{Antibactirial effect of ethanol extract of C.colocynthis fruit}

The results obtained from the fruit of CitrullusColocynthis extract for antibacterial effect on different bacteria, were shown in the table 3. 2 .

Table 3.2: Antibacterial effect of C.colocynthis fruit ethanol extract against different types of bacteria

\begin{tabular}{|c|c|c|}
\hline Type of bacteria & $\begin{array}{c}\text { Concentration } \\
\mathrm{mg} / \mathrm{ml}\end{array}$ & $\begin{array}{c}\text { Inhibition zone } \\
(\mathrm{mm})\end{array}$ \\
\hline Haemophils & 200 & 19 \\
influenza & 100 & 11 \\
& 50 & 0.3 \\
\hline Streptococcus & 200 & 22 \\
Pyogens & 100 & 18 \\
& 50 & 15 \\
\hline Staphylococcus & 200 & 30 \\
Aeures & 100 & 20 \\
& 50 & 14 \\
\hline Pseudomonas & 200 & 0.6 \\
& 100 & 11 \\
& 50 & 27 \\
\hline
\end{tabular}

$-15 \mathrm{~mm}$ and more indicate antibacterial activity

-Less than $15 \mathrm{~mm}$ indicate no antibacterial activity

\subsection{Antifungal effect of ethanol extract of C.colocynthisfruit:-}

The results obtained from the fruit of CitrullusColocynthisextract for antifungal effect,was shown in table 3.3

Table 3.3: Antifungal effect of C.colocynthis fruit ehanol extractagainsTrichophton.

\begin{tabular}{|c|c|c|}
\hline No & $\begin{array}{c}\text { Concentration of crude } \\
\text { extract } \mathrm{mg} / \mathrm{ml}\end{array}$ & $\begin{array}{c}\text { Inhibition zone }(\mathrm{mm}) \\
\text { Trichophton }\end{array}$ \\
\hline 1 & 200 & 16 \\
\hline 2 & 100 & 12 \\
\hline 3 & 50 & 0.90 \\
\hline
\end{tabular}

$-15 \mathrm{~mm}$ and more indicate antifungal activity

-Less than $15 \mathrm{~mm}$ indicate no antifungal activity

Phytochemical tests were carried out on ethanol extract for alkaloids, flavonoids, sterols and terpens, tannins, saponins

Volume 4 Issue 11, November 2015 


\section{International Journal of Science and Research (IJSR) \\ ISSN (Online): 2319-7064 \\ Index Copernicus Value (2013): 6.14 | Impact Factor (2014): 5.611}

and anthraquinones. The detailed of phytochemical screening in form of ethanol extract is given in Table 3.1. Phytochemical screening portrays that present of alkaloids, flavonoids, sterols and terpens, and showed negative results for tannins, saponins and anthraquinone.

Antibacterial activity of crude ethhanolic extract of C.colocynthifruit showed that high concentration of extract $200 \mathrm{mg} / \mathrm{ml}$ as given in Table 3.2, more active than $100 \mathrm{mg} / \mathrm{ml}$ and $50 \mathrm{mg} / \mathrm{ml}$ against Streptococcus pyogens $\mathrm{S}$, Haemophils influenzas, Staphylococcus aeures $S$, on the other hand low concentrations showed more antibacterial activity against Pseudomonas $S$, and that may be due to the cell membrane of this type of bacteria,or may due tothe idea that cytoplasm cell of this kind of bacteria resists high concentrated solutions, also may be due to osmotic pressure.

The antifungal activity of crude extract C.colocynthis fruit was observed to be very strong, as given in Table 3.3, high concentration $200 \mathrm{mg} / \mathrm{ml}$ showed antifungal activity against Trichophton. But Low concentration $100 \mathrm{mg} / \mathrm{ml}, 50 \mathrm{mg} / \mathrm{ml}$ did not show antifungal activity against Trichophton.

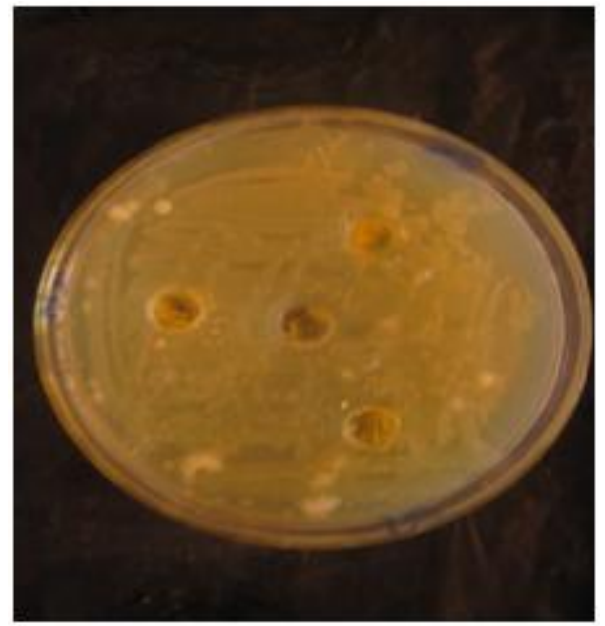

Figure 3.1: Fruit extract against Tricophton

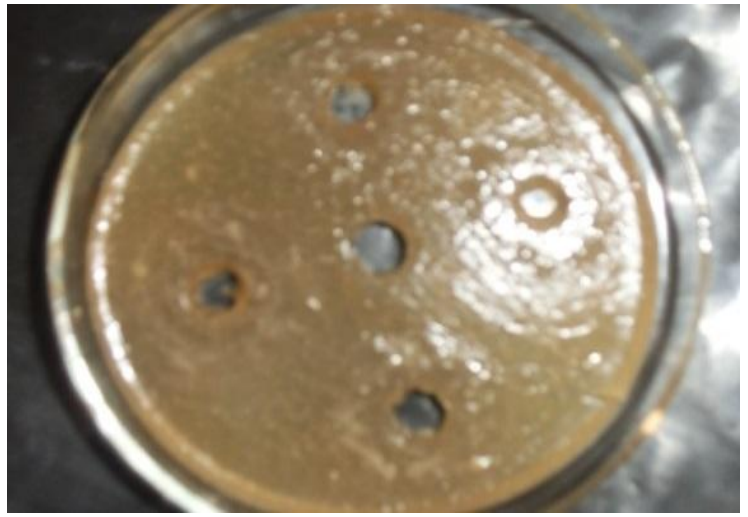

Figure 3.2: Fruit extract against Staphylococcus Aeures bacteria

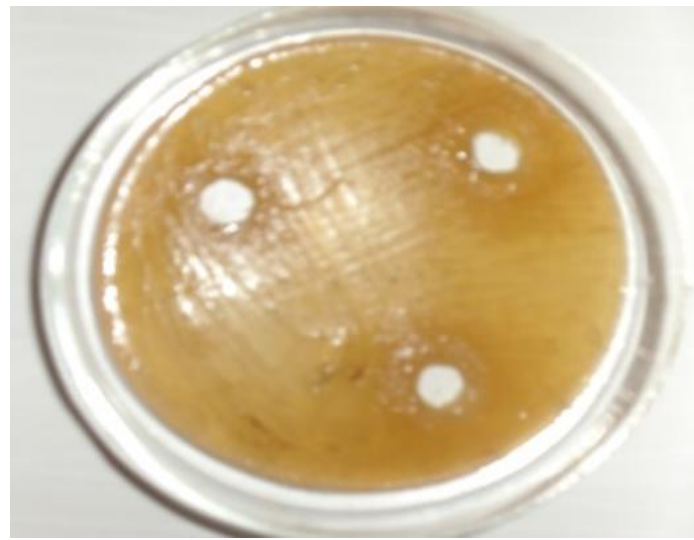

Figure 3.3: Fruit extract against Streptococcus Pyogens bacteria

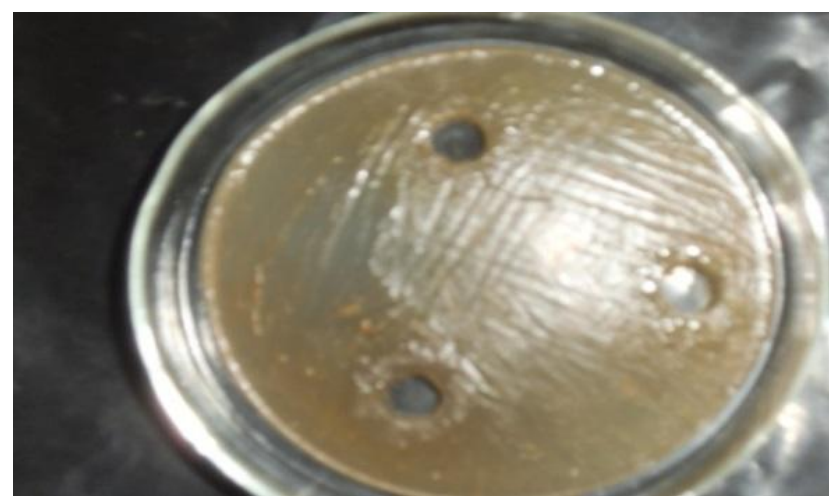

Figure 3.4: Fruit extract against Haemophils Influenza bacteria

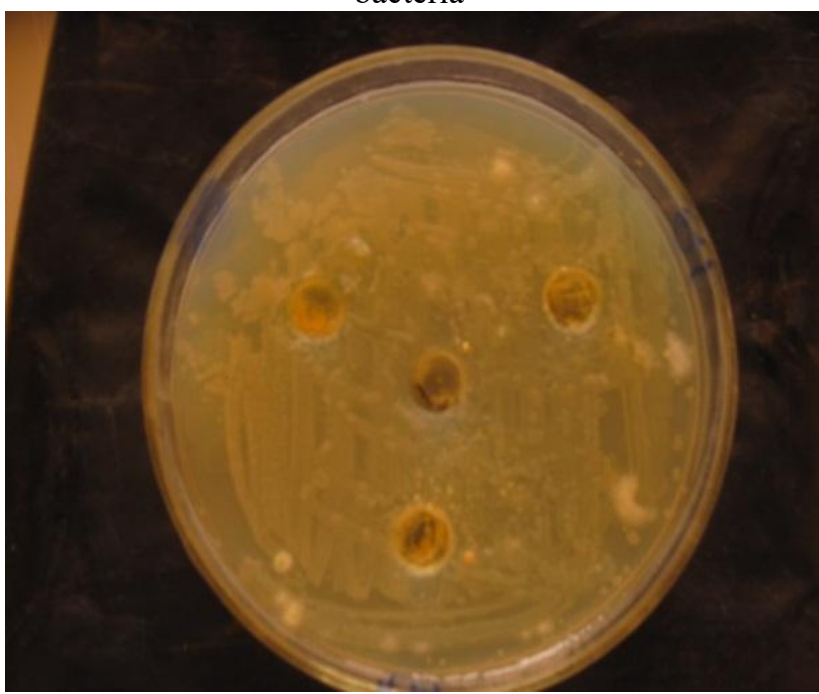

Figure 3.5: Fruit extract against Pseudomonas bacteria

\section{Conclusions and Recommendation}

Crude ethanolic fruit extract of C.colocynthis with high concentrations has good antimicrobial activity with three types of bacteria and also with fungi under study and low concentrations were more active with one type of bacteria under study. The folk medicinal use as aboard spectrum antimicrobial agent was validated. More investigations are needed to isolate constituents in order to study antimicrobial 


\section{International Journal of Science and Research (IJSR) \\ ISSN (Online): 2319-7064 \\ Index Copernicus Value (2013): 6.14 | Impact Factor (2014): 5.611}

activity of every constituent individually. The other parts, leaves, roots, etc of C.colocynthis plant should studied.

\section{References}

[1] Najafi, Shahala; Sanadgol, Nima; Nejad, BatolSadeghi; Beragi,Maryam Ashefteh and SanadgolEhsan (2010) Phytochemical screening and antibacterial activity of C.Colocynthis against Staphylococcus aureas, ZabolUnivesity, Iran, Journal of medicinal plants Research volume4(22), pp21-25.

[2] Memon, Usman;Brohi, Abdulhakeem; Ahamed, Syedwasee- muddin; Azhar, Iqbal and Bano, Husan (2003) antibacterial activity of C.Colocynthis, Institute of pharmacy, university of Sindh Jamshoro, Pakistan, Journal of pharmaceutical sciences volume16(1), pp1-6.

[3] Hossain, Mohammed Kamal; Sobhan, Istiak; Alan, M.Khairal; Khan, NizAhamed and FirozRemeen (2011) Selected Medicinal plants of Chittagong Hill tracts, IUCN (international union for conservation of nature), Bangladesh Contry office pp1-3.

[4] Prasad, Reddy. D. M.; Izam, Amirah and Khan. Md. MaksudurRahman (2012) Jatrophacurcas: Plant of medical benefits, Faculty of Chemical and Natural Resources Engineering, University Malaysia Pahang, Journal of Medicinal Plants Research volume 6(14) pp 9192.

[5] AbdallaAbdelrahimSatti, and AmalElsayedEdriss(2014) prelimintary phytochemical screening and activities of citrulluscolocynthis(L) schard as mosquito larvicides; World Journal of Pharmaceutical ResearchVolume 4, Issue 01,pp 1705-1720.

[6] HarborneJ.B (1998)Phytochemical Methods , ed.Halsted press, New York.

[7] Kavangh. F (1972). Analytical Microbiology, Acadimic press, New York, USA.

[8] Kumar, Bimlesh;Sandhar, KarleenKaur; Prasher, sunil; Tiwari, Prashant; Salhan, Manoj and Sharma, Pardeep (2011) A Review of Phytochemistry and Pharmacology of Flavonoids, international pharmaceutica science volume1(1) p23-24. 